JOURNAL OF PATHOLOGY, VOL. 143: 93-101 (1984)

\title{
DAMAGE AND HEALING IN THE CONDUCTING TISSUE OF THE HEART (AN EXPERIMENTAL STUDY IN DOGS INFECTED WITH TRYPANOSOMA CRUZI)
}

\author{
ZILTON A. ANDRADE, SONIA G. ANDRADE AND MOYSÉS SADIGURSKY \\ Gonçalo Moniz Research Center (FIOCRUZ/UFBa), Salvador, Bahia, Brazil
}

Received 14 November 1983 Accepted 8 December 1983

\begin{abstract}
SUMMARY
The consequences of acute inflammatory damage and chronic repair in the conducting system of the canine heart were observed after experimental Trypanosoma cruz $i$ infection of young dogs. Acute infection lasted for $18-25$ days and caused hyaline and lytic necrosis of the atrio-ventricular conducting fibres, the sinus node and the neurons in the cardiac para-sympathetic ganglia. Dogs that survived acute disease were examined after periods from 8 months to 3 years. Three main types of healing were found in the conducting system: fibrosis (diffuse and/or focal), sclero-atrophy and fatty infiltration. No signs of active chronic inflammation were present, although small focal residual accumulations of mononuclear cells were present in some animals. No evident electrocardiographic alterations were elicited by the presence of such cicatricial lesions. The animal model appears worthwhile for the study of the healing process in conducting tissue of the heart and for the better understanding of the asymptomatic phase of $T$. cruzi infection in man.
\end{abstract}

KEY WORDS-Conducting tissue, Chagas' disease, myocarditis.

\section{INTRODUCTION}

The specialized tissue of the heart for the formation and conduction of the electric stimuli for contraction is composed of the sinus node (the normal pacemaker), internodal tracts, atrioventricular node, His bundle and its branches and the Purkinje fibres. This important system can be damaged by disease and arrhythmias of several types and severity may appear therefrom. ${ }^{1}$ It is generally assumed that the myo-neural cells of this system are unable to regenerate and that destructive lesions are followed by scarring. However, no direct experimental evidence is so far available to indicate how the specialized tissues of the heart undergo repair. Thus, several end-stage types of lesions seen in human conducting tissue have been variously interpreted as of degenerative, inflammatory or vascular origins. ${ }^{2}$ It seems that a

\footnotetext{
Supported by Grant No. 2222.8.175/80) from the Brazilian
} Research Council (CNPq)

0022-3417/84/060093-09\$01.00

(C) 1984 by John Wiley \& Sons, Ltd. better understanding of the pathological changes would be gained if one could have an experimental model for a controlled study of the process of repair within the conducting tissues of the heart.

During experimental studies with Trypanosoma cruzi infection in young dogs it became apparent that the severe myocarditis present extended into the conducting tissue, sometimes causing extensive damage to it. ${ }^{3}$ Furthermore, such myocarditis eventually subsided almost completely permitting the healing process to take place. ${ }^{4}$ Thus, it was apparent that $T$. cruzi infection in dogs could offer for the first time a suitable model for the controlled study of damage and repair in delicate and peculiar structures such as those of the conduction system of the heart.

The present study describes the morphological changes which appear in the conducting system during acute $T$. cruzi myocarditis in dogs and its aftermath 8 months to 3 years following clinical cure. 


\section{MATERIAL AND METHODS}

Fifty mongrel dogs of both sexes, $2-5$ months old, were inoculated intraperitoneally with citrated mouse blood containing $4-6 \times 10^{5} \mathrm{~T}$. cruzi trypomastigotes per $\mathrm{kg}$ body weight, of the strains 12 SF (Sāo Felipe-Bahia) or Colombian strain. ${ }^{5}$

They all developed positive parasitaemias at approximately 5-7 days after inoculation and showed evident signs of disease (loss of appetite, dyspnoea) around day 15 .

There was high mortality from day 19 to 23 . Thirteen animals that died or were sacrificed in the height of the acute phase were selected for special study of the conduction system of the heart (see Table I). Nine dogs survived acute infection and started to recover by day $30 \mathrm{on}$. Three of them were treated during the acute phase with a nitrofuranic drug, Bayer's nifurtimox ${ }^{6}$ and six recovered spontaneously. Although parasitaemia became negative, xenodiagnosis and/or the complement fixation test remained positive for all animals. Serological titres ranged from $1: 16$ to $1: 128$. These animals appeared healthy and had repeated electrocardiograms within normal limits. They were sacrificed after 8 months to 3 years following inoculation (see Table II).

During the acute and chronic stages of these experiments several electrocardiograms (ECG) were recorded from each animal and compared with their pre-infection ECGs. A one single channel apparatus was used, all 12 classical leads were taken with small metallic needles placed under the skin serving as electrodes.

Autopsies were performed as soon as possible after death. The heart was fixed in totum. A 10 per cent buffered formalin solution was injected into the cardiac chambers with the vessels ligated. The heart was gently distended in a diastolic position and placed in formalin for 2-4 days before opening. The sinus node was studied according to Hudson. $^{7}$ The atrio-ventricular node, His bundle and proximal portions of its branches as well as the internodal approaches to the AV node, were studied by the Lev's method. ${ }^{8}$ The serial sections obtained were mounted on continuous transparent plastic tapes according to the technique described by Pickett and Sommers. ${ }^{9}$ After staining with the Masson's trichrome method the sections were examined with a special device adapted to the microscope. An average of 600 sections from the SA node and 3000 from the atrio-ventricular system were examined for each case. Selected sections from every case were taken apart, mounted on glass slides and stained with haematoxylin and eosin, Weigert-Van Gieson method for collagen and elastic fibres, periodic acid-Schiff (PAS) and Gomori's silver method for reticulum. Seven dogs, two males and five females, were not infected and served as normal controls for

Table I-General data on 13 dogs with acute experimental Trypansoma cruzi* infection used to study changes in the conducting tissue of the heart

\begin{tabular}{|c|c|c|c|c|c|c|}
\hline \multirow[b]{2}{*}{ Dog No. } & \multirow{2}{*}{$\begin{array}{l}\text { Age } \\
\text { (months) }\end{array}$} & \multirow[b]{2}{*}{ Sex } & \multirow{2}{*}{$\begin{array}{l}\text { Initial weight } \\
(\mathrm{kg})\end{array}$} & \multicolumn{2}{|c|}{$\begin{array}{l}\text { Parasitaemia } \\
(50 \text { fields, } 400 \times \text { ) }\end{array}$} & \multirow{2}{*}{$\begin{array}{l}\text { Duration of } \\
\text { infection } \\
\text { (days) }\end{array}$} \\
\hline & & & & Min. & Max. & \\
\hline 1 & 3 & $\mathrm{~F}$ & $2 \cdot 25$ & 2 & 22 & 19 \\
\hline 2 & 3 & $F$ & 1.75 & 1 & 47 & 22 \\
\hline 3 & 3 & F & $1 \cdot 60$ & 5 & 70 & 23 \\
\hline 4 & 3 & $\mathrm{~F}$ & 1.35 & 1 & 25 & 21 \\
\hline 5 & 3 & $\mathbf{F}$ & 1.50 & 1 & 26 & 22 \\
\hline 15 & 2 & $\mathbf{M}$ & $2 \cdot 00$ & 7 & 79 & 26 \\
\hline 24 & 2 & $F$ & 1.08 & 19 & 388 & 24 \\
\hline 26 & 2 & F & $1 \cdot 11$ & 2 & 87 & 25 \\
\hline 29 & $2 \cdot 5$ & $F$ & $2 \cdot 17$ & 3 & 15 & 25 \\
\hline 33 & $2 \cdot 5$ & $\mathrm{~F}$ & 1.72 & 2 & 7 & 23 \\
\hline 36 & 2 & $\mathrm{~F}$ & 1.40 & 8 & 55 & 19 \\
\hline 39 & 2 & $\mathrm{~F}$ & $2 \cdot 20$ & 1 & 33 & 20 \\
\hline 40 & 2 & $F$ & $2 \cdot 00$ & 1 & 8 & 29 \\
\hline
\end{tabular}

* Strain: 12-SF (Bahia), except dog 15 (Colombian strain). 
serological, electrocardiographic and morphological comparison.

\section{RESULTS}

During the acute phase of the infection all the dogs exhibited severe myocarditis. Electrocardiographic examination showed alterations from day 7 on. These included atrial fibrillation, nodal rhythm, wandering pacemaker, inverted $T$ waves, alterations of ST segments and, later on, complete right bundle branch block with or without anterior or posterior left hemiblock. At autopsy the hearts appeared soft and dilated. Examination of the animals on the days 18-22 after inoculation showed a diffuse and intense mononuclear cell infiltration in the myocardium, with $T$. cruzi amastigotes present within some myocardial cells. This inflammation also involved the conducting

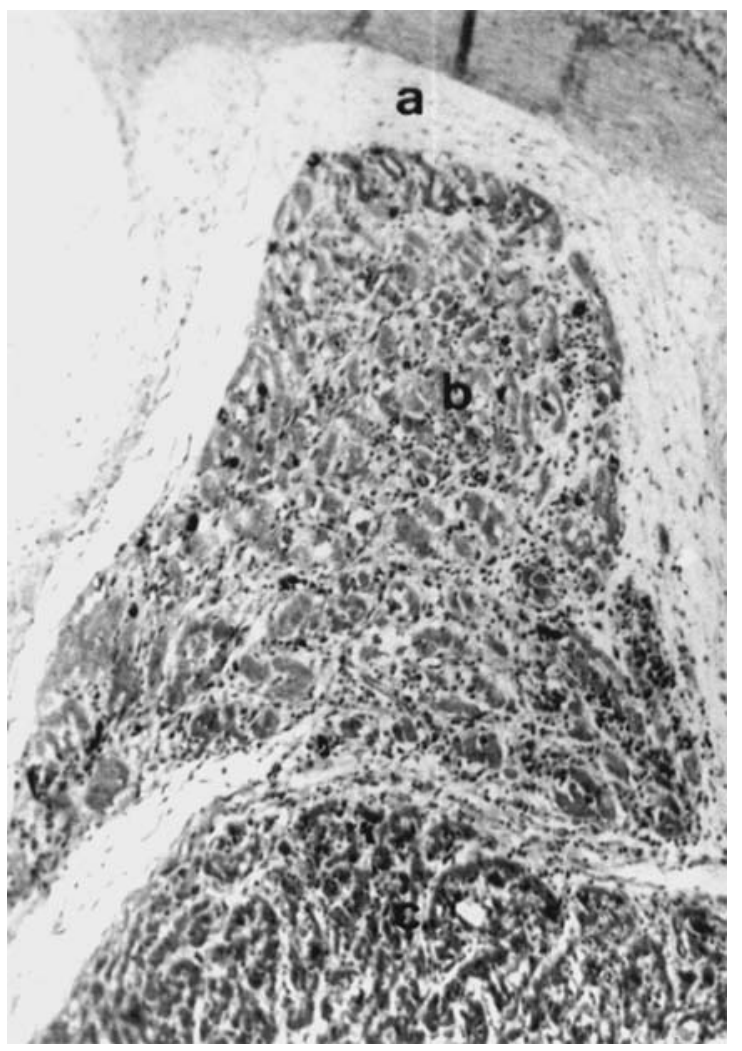

Fig. 1-His bundle showing mild round cell infiltration in a dog with acute $T$. cruzi infection of 18 days duration. There is dissociation of specific fibres and disappearance of some others (lytic necrosis) . $a=$ Central fibrous body; $b=$ bundle of His; $c=$ septal myocardium. Masson's trichrome stain, $\times 120$

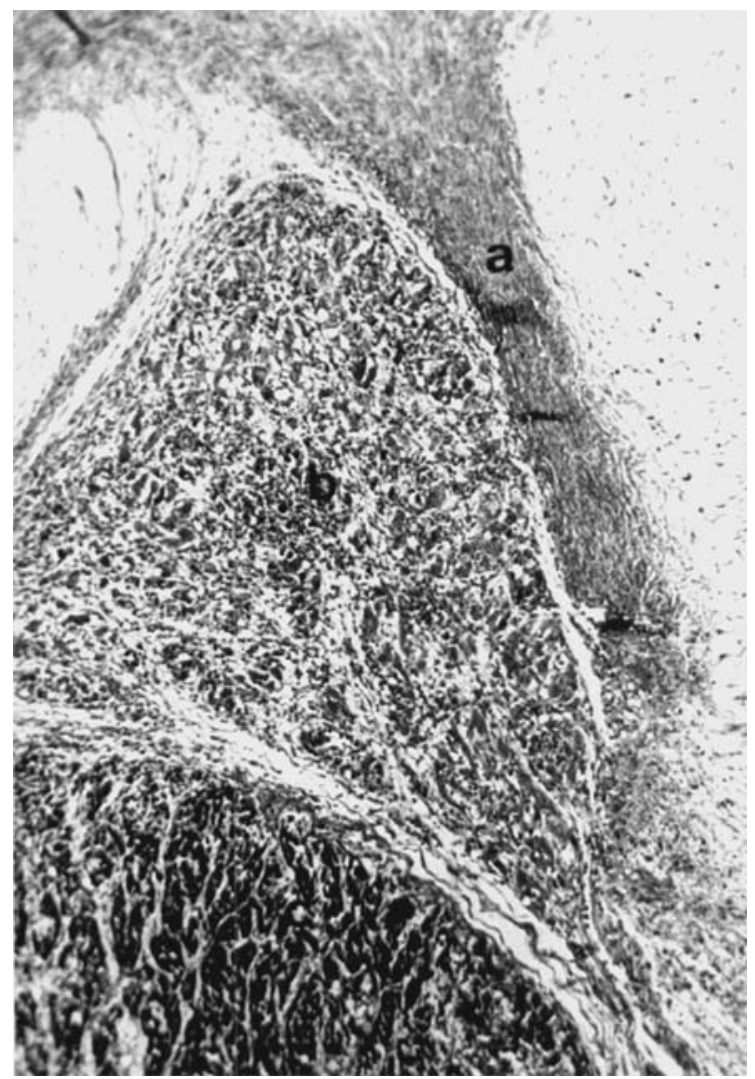

Fig. 2-Acute $T$. cruzi myocarditis involving the main bundle of His in a dog inoculated 22 days previously. Besides the mononuclear cell infiltration there are many clear spaces among the fibres representing areas of lytic necrosis. See Fig 1 legend for key. Masson's trichrome stain, $\times 100$

system. Figs $1-3$ show three degrees of changes in the His main bundle. Similar changes were present throughout the conducting system and in the sinus node. This latter structure was so infiltrated by inflammatory cells that its histological identification was difficult. Sometimes it appeared to be totally effaced with only the nodal artery and a scanty amount of the peculiar nodal stroma around it being tentatively identified. Within the mononuclear infiltration of the myocardial specific tissues there occurred lytic and hyaline necrosis of the fibres. This caused considerable loss of specialized tissue, with the appearance of vacuolated and empty spaces which were followed by collapse of the supporting stroma. Intracellular parasites could be detected in some of these lesions.

Surviving animals showed disappearance of acute electrocardiographic alterations by 2 months 
after inoculation and soon recovered appetite and became active again. During intervals from 8 months to 3 years (Table II) they were sacrificed.

The hearts were grossly within normal limits. Microscopical changes in the myocardium included patchy areas of fibrosis, focal atrophy of fibres and minute sparse collections of lymphocytes and macrophages. No evidence of chronic active inflammation could be seen in any case.

The sinus node showed considerable fatty infiltration in its surroundings and rarely in the nodal tissue proper. The fibrous stroma showed diffuse condensation and there were small focal areas of dense fibrosis. The nodal artery was little altered. There was focal intimal fibrosis and slight fibrosis and hypertrophy of the media.

The lesions in the conducting tissue were represented by foci of fibrous tissue, fatty infiltra-

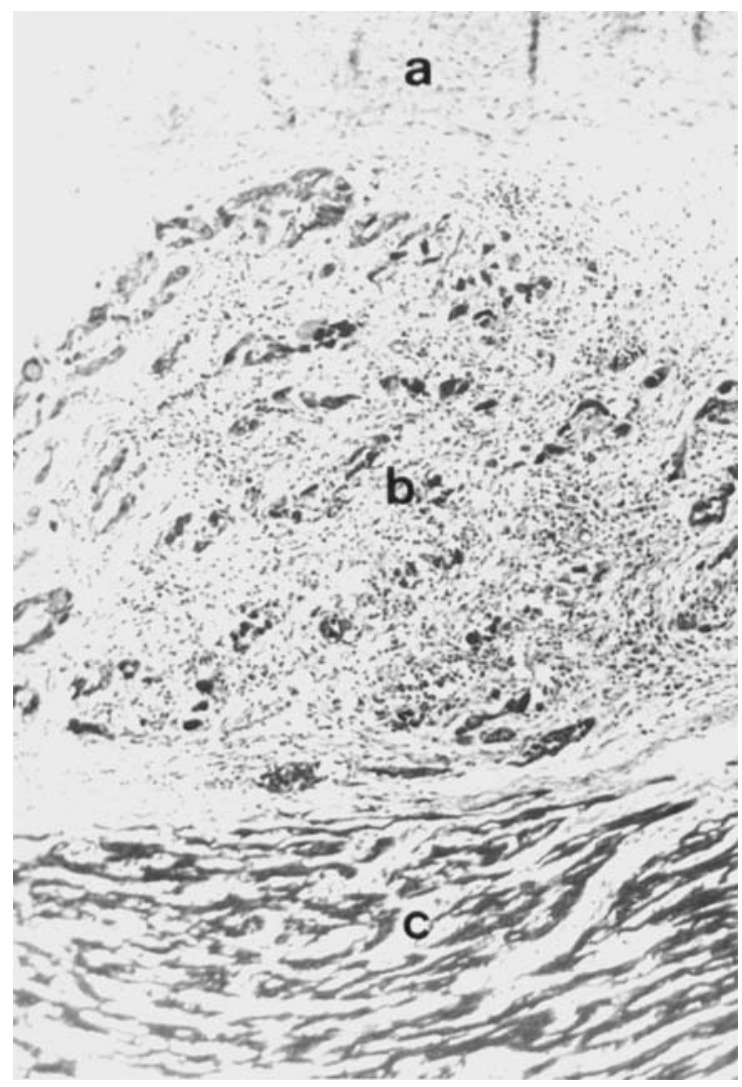

Fig. 3-Considerable inflammatory destruction of the His bundle in a dog with a 20 day old infection by $T$. cruzi. Almost 80 per cent of the conducting fibres have been destroyed. Sec Fig. 1 legend for key. Masson's trichrome stain. $\times 120$ tion and sclero-atrophy, occasionally with little focal mononuclear cell infiltration (Fig. 4). The AV node and the distal portion of the main bundle and the right bundle branch were the main areas involved. Several areas of fibrous (cicatricial) tissue appeared in the interventricular septum especially involving the right portion of it. Fatty infiltration was prominent in two cases. It appeared in the penetrating part of the main bundle in one case and in the half portion of the distal main bundle in another case. This latter animal had been treated with Nifurtimox (Bayer) plus corticoid (Fig. 5). Fatty tissue was also present in the AV node, and in one instance, it interrupted almost 70 per cent of the right bundle branch (Fig. 6 ), just in its beginning from the main bundle. Sclero-atrophy was represented by an extreme degree of atrophy of specific fibres while the

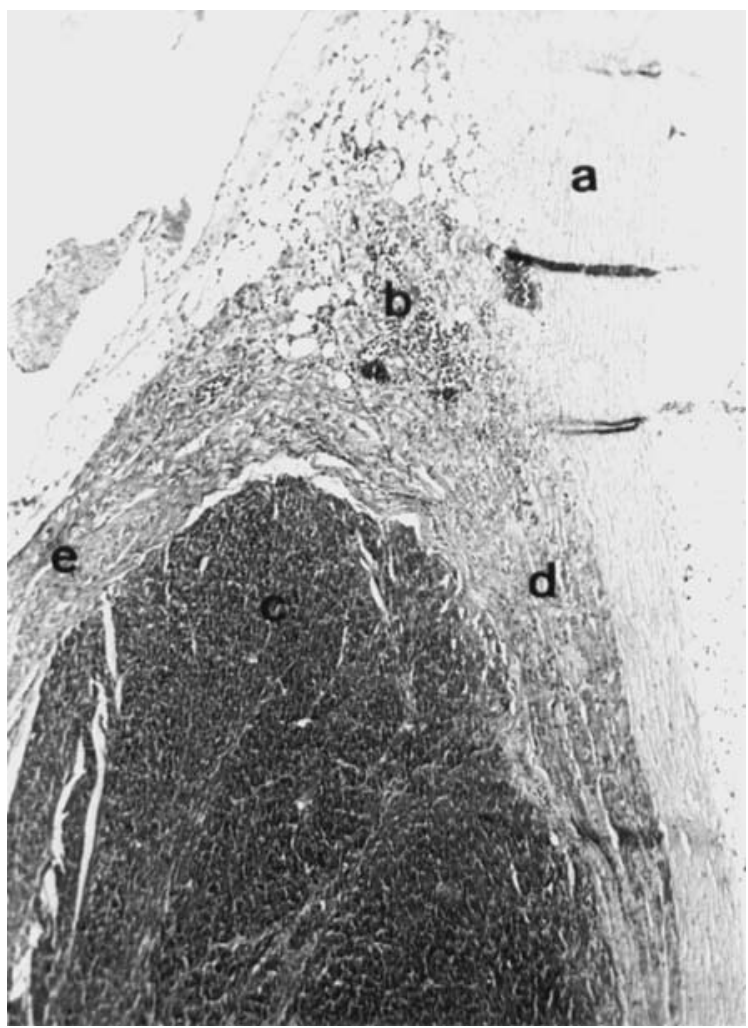

Fig. 4-Diffuse fibrosis, some patchy areas of mononuclear cell accumulations and focal fatty infiltration are present in the conducting tissue of a dog that had acute $T$. cruzi infection 3 years ago. $a=$ Central fibrous body; $b=$ His bundle; $c=$ septal myocardium; $d=$ right bundle branch; $e=$ left bundle branch (anterior division). ECG showed transient sinus arrhythmia only. Haematoxylin and eosin, $\times 70$ 
Table II-General data on dogs which survived acute infection with Trypanosoma cruzi and were later utilized to study the pathology of the conducting tissue of the heart

\begin{tabular}{llllll}
\hline Dog No. & $\begin{array}{l}\text { Initial age } \\
\text { (months) }\end{array}$ & Sex & $\begin{array}{l}\text { Initial } \\
\text { weight } \\
(\mathrm{kg})\end{array}$ & $\begin{array}{l}\text { Duration of } \\
\text { infection } \\
\text { (months) }\end{array}$ & $\begin{array}{l}\text { T.cruzi } \\
\text { strain }\end{array}$ \\
\cline { 1 - 3 } \cline { 5 - 6 } & 5 & $\mathrm{M}$ & $8 \cdot 00$ & 36 & $12 \mathrm{SF}$ \\
14 & 5 & $\mathrm{M}$ & $5 \cdot 00$ & 36 & $12 \mathrm{SF}$ \\
16 & 2 & $\mathrm{M}$ & $2 \cdot 00$ & 19 & Colombian \\
18 & 2 & $\mathrm{~F}$ & $1 \cdot 20$ & 8 & $12 \mathrm{SF}$ \\
21 & 2 & $\mathrm{M}$ & $1 \cdot 20$ & 28 & $12 \mathrm{SF}$ \\
38 & $2 \cdot 5$ & $\mathrm{~F}$ & $2 \cdot 35$ & 18 & $12 \mathrm{SF}$ \\
47 & $2 \cdot 5$ & $\mathrm{~F}$ & $2 \cdot 40$ & 9 & Colombian \\
49 & $2 \cdot 5$ & $\mathrm{~F}$ & $2 \cdot 60$ & 9 & Colombian \\
50 & $2 \cdot 5$ & $\mathrm{~F}$ & $2 \cdot 60$ & 9 & Colombian \\
\hline
\end{tabular}

stroma appeared undisturbed, although partially collapsed. Such change was seen more often in the bundle branches especially in the right side (Fig. 7).

Fibrous scarring was seen as a prominent change

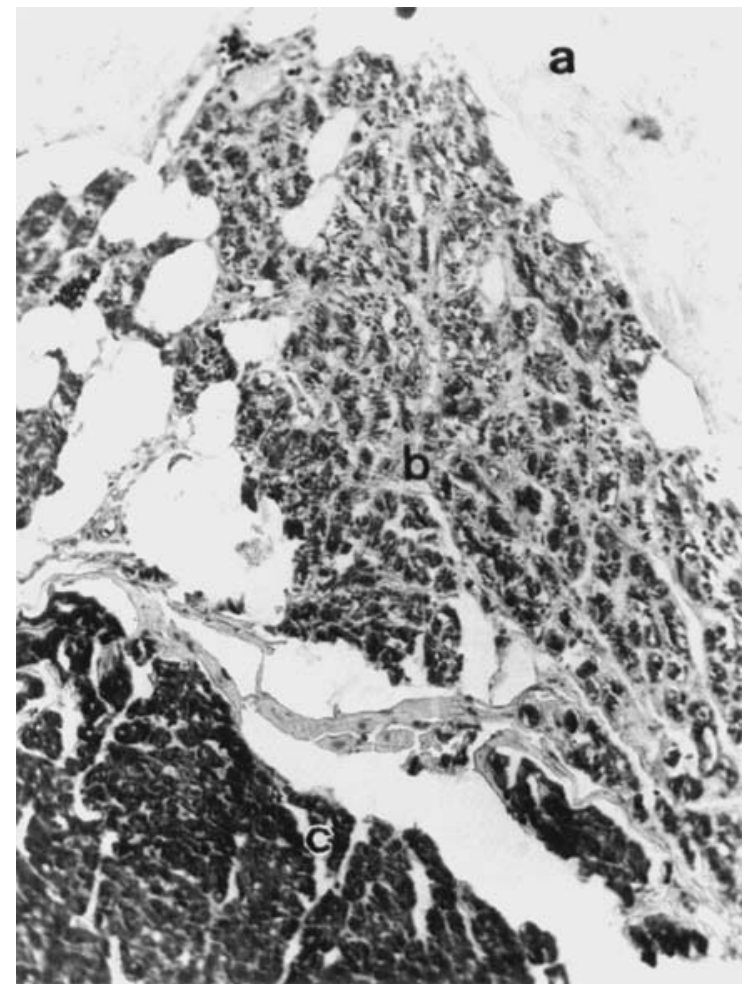

Fig. 5-Bundle of His presenting areas of fatty infiltration and a fine and diffuse interstitial fibrosis. There is no inflammation. Specimen is from a dog that recovered from acute $T$. cruzi myocarditis 9 months ago. See Fig. 4 legend for key. Masson's trichrome stain. $\times 150$ twice in the AV node, three times in the main bundle and once in the right bundle branch. A frequent finding was a diffuse interstitial fibrous thickening better seen at the AV node (Fig. 8). Changes in the 12 lead electrocardiograms, during the period of observation were not marked. Five animals developed a prolongation in PR interval,

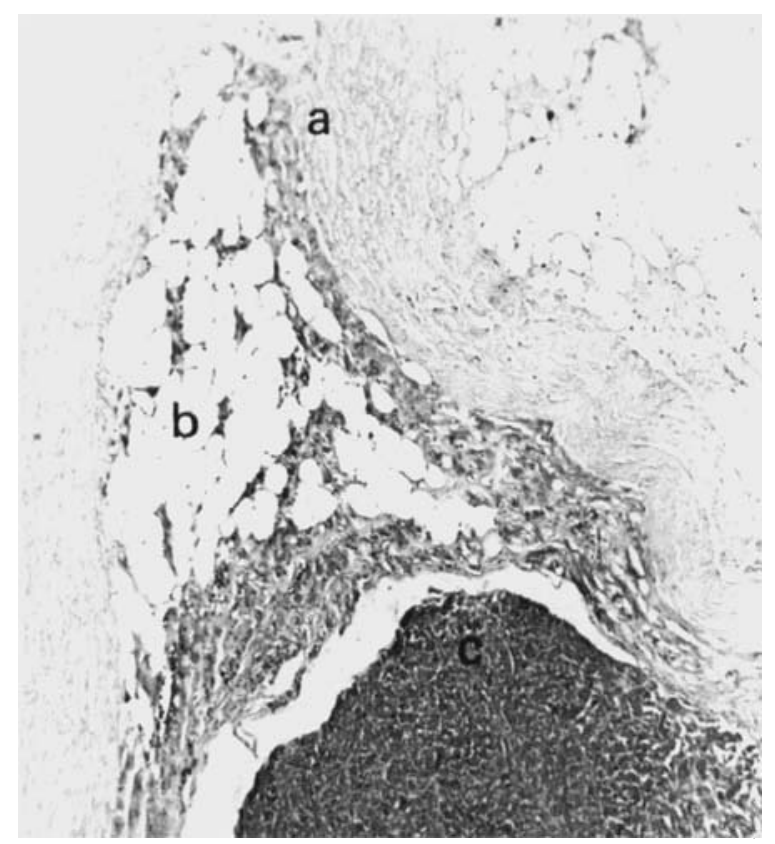

Fig. 6-Marked fatty infiltration replacing the His bundle in a dog that recovered from acute $T$. cruzi infection after treatment with a nitrofuranic drug and corticoid and remained apparently healthy for 18 months when it was sacrificed. Serial sectioning showed that about 70 per cent of the bundle was replaced by fat in that area. ECG did not show cardiac block. See Fig. 4 legend for key. Haematoxylin and eosin, $\times 120$ 


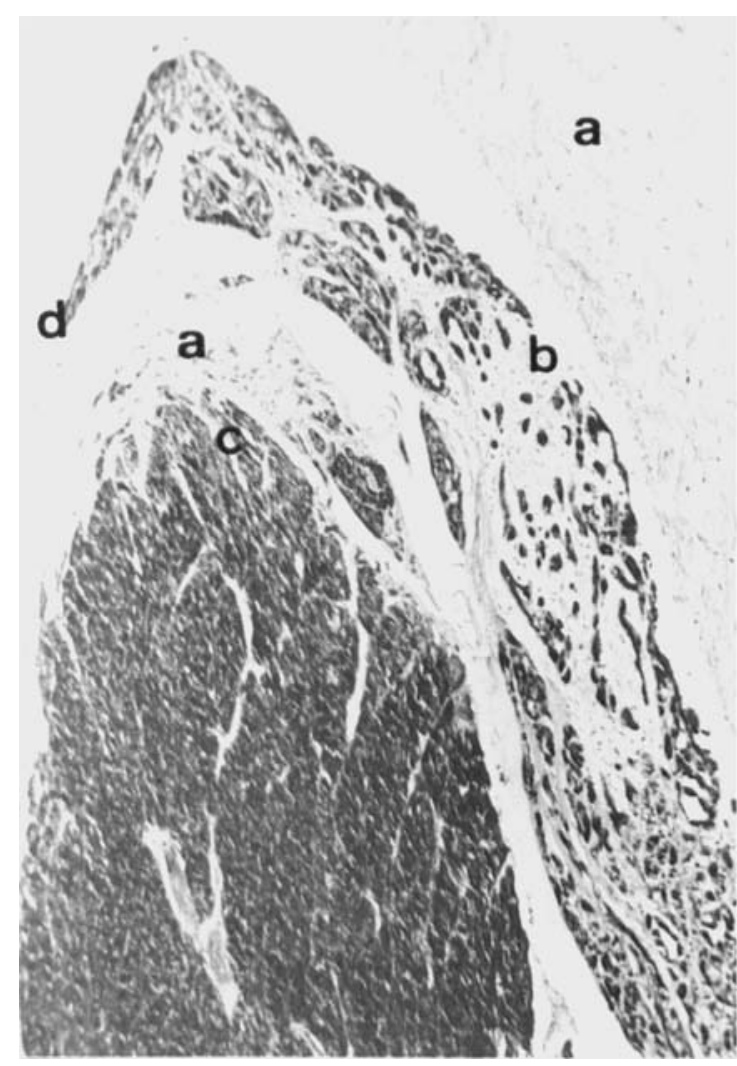

Fig. 7-Areas of sclero-atrophy in the right bundle branch. Dog had acute $T$. cruzi infection 8 months ago. ECG showed morphology of incomplete right bundle branch block. $a=$ Central fibrous body; $b=$ right bundle branch; $c=$ septal myocardium; $d=$ left bundle branch. Masson's trichrome stain, $\times 100$

although in the majority of them, heart rates had dropped considerably. In one case electrocardiographic changes, compatible with right bundle branch block, which were not present during the acute phase, appeared after 260 days of inoculation. In this case the right bundle branch and the right hemi-portion of the main bundle were replaced by fibrous tissue.

Similar changes as described above were also seen in the autonomic nerve ganglia present in the epicardium and inter-atrial septum. During acute infection there were mononuclear cell infiltration and neuronal destruction (Fig. 9) and during the recovering stage, when inflammation had subsided, there appeared fibrous replacement (Fig. $10)$.

The tissues around the atrio-ventricular node (approaching tracts to the AV node) also showed

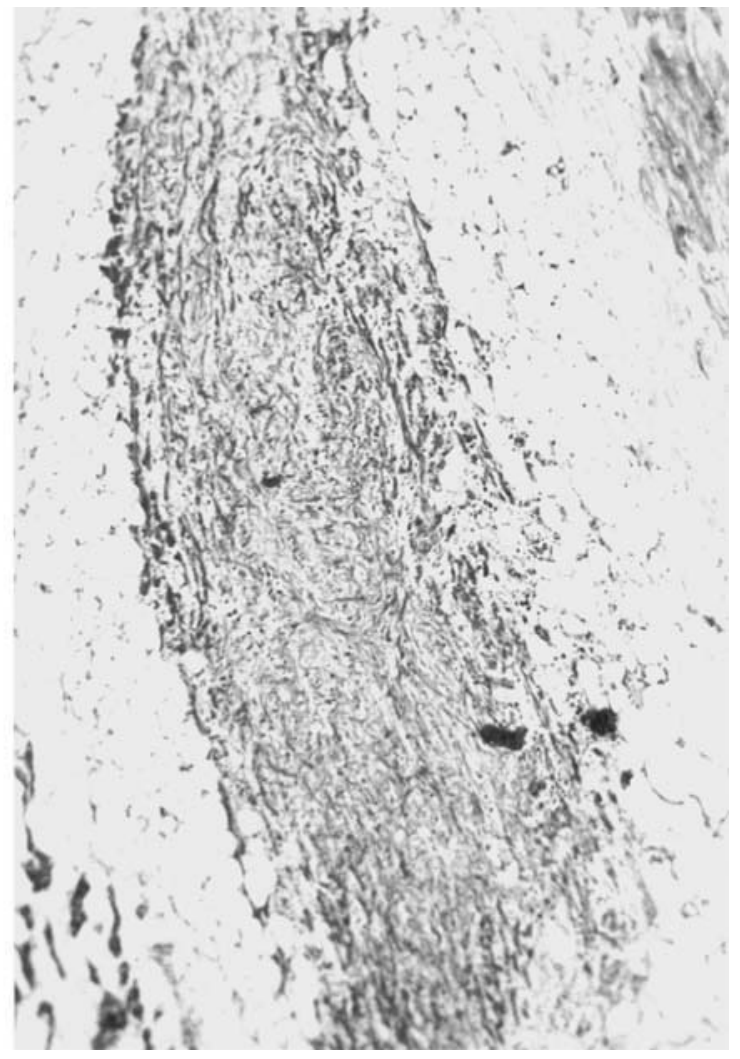

Fig. 8-Diffuse interstitial fibrosis, atrophy of specific fibres and mild residual round cell infiltration present in the atrio-ventricular node. This dog had acute T. cruzi infection 3 years ago. Masson's trichrome stain, $\times 120$

severe inflammatory changes during the acute infection and late fibrous replacement and fatty infiltration.

\section{DISCUSSION}

An experimental study of the healing process within the conducting system of the heart has not been reported probably due to the lack of an appropriate model. The infection of young dogs with T. cruzi, followed by severe acute disease and by clinical cure appears to be a promising model. Dogs have a conducting system similar to that of man, ${ }^{10-13}$ can be easily infected with $T$. cruzi $i^{13}$ and the severe myocarditis which develops during acute infection can be suppressed with drugs at any time. $^{6}$

Acute $T$. cruzi myocarditis is known to involve the conducting tissue of both $\operatorname{man}^{14}$ and $\operatorname{dog}^{13}$ causing lytic and hyaline necrosis of specific fibres. 


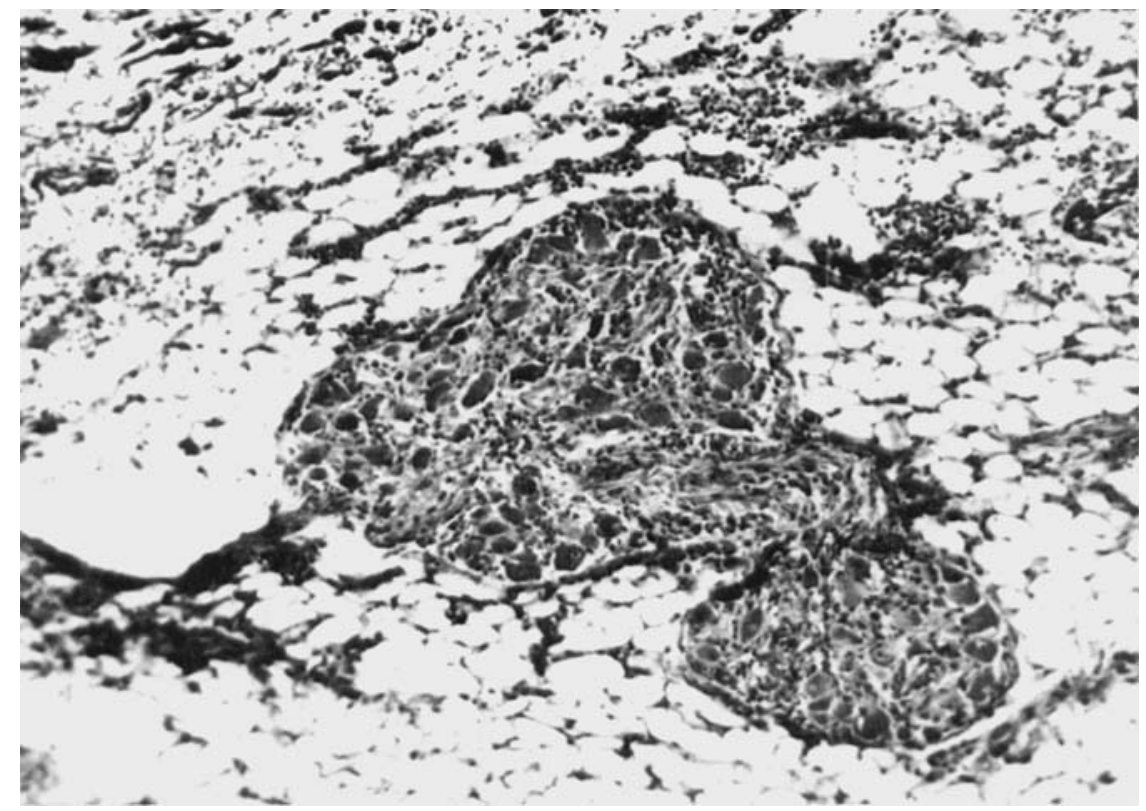

Fig. 9-Sub-epicardial autonomic nervous ganglia of a dog with acute T. cruzi infection. There are diffuse mononuclear cell infiltration, interstitial edema, and neuronal degeneration and necrosis. Haematoxylin and eosin, $\times 100$

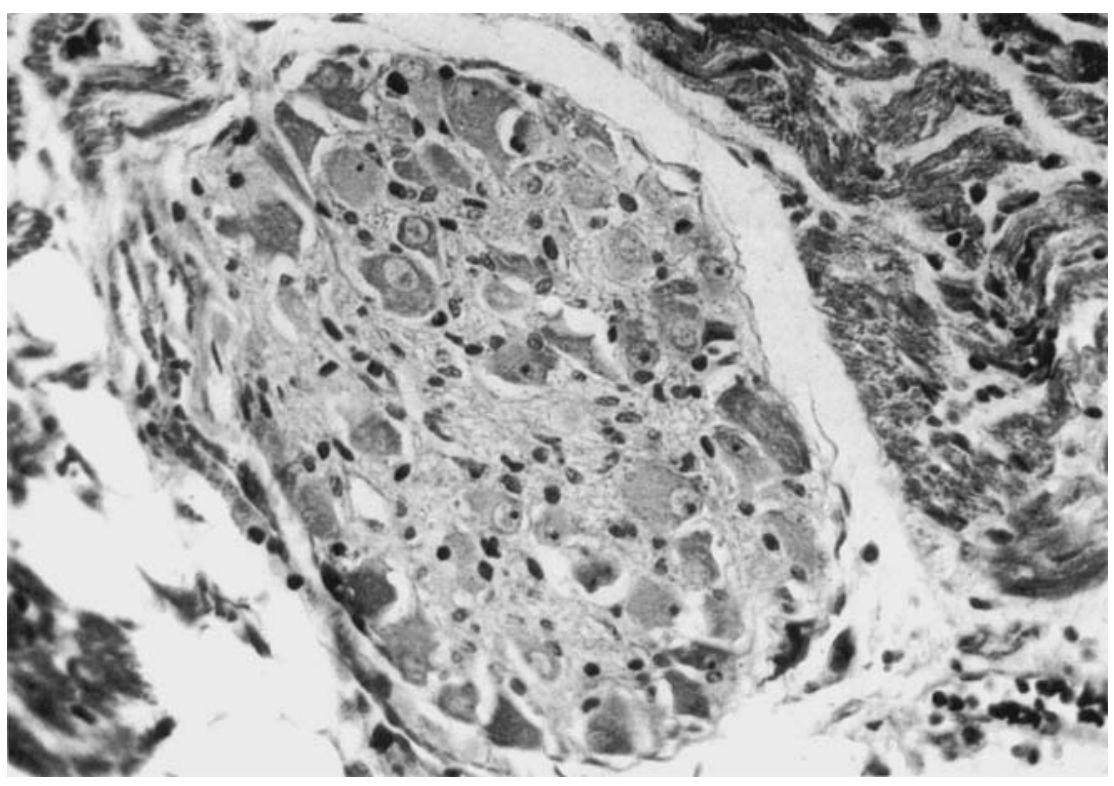

Fig. 10-Interstitial fibrosis, diminution of the number of neurons seen in a nerve ganglion near the right atrial wall. Dog 8 months after the acute phase of $T$. cruzi infection. Haematoxylin and eosin, $\times 150$

The cause of such necrosis in non-parasitized cells remains obscure at present. The possibility of toxic, anoxic or metabolic injury cannot be ruled out. Ribeiro dos Santos and Hudson ${ }^{15}$ have presented evidence from in vitro studies that $T$. cruzi antigen sensitization of cell membrane could be followed by cellular and/or humoral immunemediated lysis. 
The findings in the present study revealed that three main forms of healing can result from the acute necrotic-inflammatory injury to the canine conducting tissue: fibrosis, sclero-atrophy and fatty infiltration. Fibrosis is a quite common and stereotyped form of repair anywhere and needs no further comment. Sclero-atrophy occurs frequently in the conducting system of man and represents a main lesion found in cases of idiopathic atrioventricular block. ${ }^{16}$ It is characterized by the presence of considerable atrophy of the conducting fibres while the normal stroma persists as a loose connective framework. It can sometimes collapse and become a dense acellular fibrous tract. Sclero-atrophy has been thought to result from progressive vascular ischaemia ${ }^{17}$ although this has been disputed by others. ${ }^{18}$ No important vascular involvement was apparent in the present material.

Fatty replacement is also frequently observed in lesions affecting the conducting tissue of $\operatorname{man}^{1,19}$ and sometimes appears as a sole and prominent lesion in complete atrio-ventricular block. ${ }^{20}$ It has been correlated with obesity and aging, and is usually considered as a primary degenerative process rather than a peculiar process of repair within the conducting tissue. It is a curious and paradoxical 'healing' process, since fatty tissue is the least conducting of all living tissues, probably due to its low electrolyte content. ${ }^{21}$

Similar mechanisms of damage and defective repair during $T$. cruzi infection were also observed in the para-sympathetic nervous ganglia of the heart. Loss of neurons in the autonomic nervous system is an important feature of Chagas' disease. Its pathogenesis and significance are controversial. Damage during acute infection seems to be an important mechanism of neuronal loss, as suggested by Köberle. ${ }^{22}$

Another important aspect observed in the present material is that several large or patchy cicatricial areas within the conducting tissue can exist without eliciting alterations in the classical electrocardiogram. This has considerable implications regarding the problem of Chagas' disease in man. It is well known that people who recover from acute Chagas' disease may remain asymptomatic for years or even for a lifetime, although they do not eliminate the infection. Refined methods of cardiac examination may detect conduction disturbances in these individuals. ${ }^{23}$ To the cardiologists these findings serve to unmask early cardiac signs of chronic progressive Chagas' myocarditis, which means an ominous prognosis. The administration of conduction depressing drugs, such as ajmaline ${ }^{24.25}$ can even make the disturbances detectable by routine electrocardiography. However, there is a possibility that the results of some of these functional studies may depend on the presence of cicatricial areas rather than active lesions in the conducting tissue of asymptomatic subjects with $T$. cruzi infection, as observed in the present study.

\section{REFERENCES}

1. Davies MJ. Pathology of Conducting Tissue of the Heart. London: Butterworth, 1971.

2. Lev M, Bharati S. Lesions of the conduction system and their functional significance. In: Pathology Annual. New York: Appleton-Century-Crofts, 1974: 157-207.

3. Andrade ZA, Andrade SG, Sadigursky M, Lima JAC. Doença de Chagas experimental no cão. Relação morfológica e electrocardiográfica na fase aguda da infecção. Arq Bras Cardiol 1980; 35: 485.

4. Andrade ZA, Andrade SG, Sadigursky M, Maguire JH. Experimental Chagas' disease in dogs. A pathologic and ECG study of the chronic indeterminate phase of the infection. Arch Path Lab Med 1981; 105: 460.

5. Federici EE, Abelmann WB, Neva FA. Chronic and progressive myocarditis and myositis in $\mathrm{C} 3 \mathrm{H}$ mice infected with Trypanosoma cruzi. Am J Trop Med Hyg 1964; 13: 272.

6. Andrade SG, Andrade ZA, Sadigursky M. Combined treatment with a nitrofuranic and a corticoid in experimental Chagas' disease in the dog. Am J Trop Med Hyg 1980; 29: 766.

7. Hudson REB. The human pacemaker and its pathology. Brit Heart J 1960; 22: 153.

8. Lev, M. The normal anatomy of the conduction system in man and its pathology in atrioventricular block. Ann New York Acad Sci 1964; 3: 817.

9. Pickett P, Sommer JR. Thirty-five $\mathrm{mm}$ film as mounting base and plastic spray as cover glass for histologic sections. Arch Path 1960; 69: 239.

10. Lumb G, Shacklett RS, Dawkins WA. The cardiac conduction tissue and its blood supply in the dog. Am J Path 35: 467.

11. James TN. Anatomy of the sinus node of the dog. Anat $\operatorname{Rec} 1962$; 143: 251.

12. Isaacson $R$, Boucek RJ. The atrioventricular conduction tissue of the dog. Histochemical properties; influence of electric shock. Am Heart J 1968; 75: 206 .

13. Andrade ZA, Andrade SG. A patologia da doença de Chagas experimental no cão. Mem Inst Oswaldo Cruz 1980; 75: 77. 
14. Andrade ZA, Miziara HL. Alteraçoes do sistema de gênese e condução do estimulo cardíaco na fase aguda da doença de Chagas humana. Arq Bras Cardiol 1983; 40: 233.

15. Ribeiro dos Santos R, Hudson L. Denervation and the immune response in mice infected with Trypanosoma cruzi. Clin Exp Immunol 1981; 44: 349.

16. Lenègre J. Etiology and pathology of bilateral bundle branch block in relation to complete heart block. Prog Cardiovasc Dis 1964; 6: 409.

17. Hudson REB. Cardiovascular Pathology, Vol. 1, Chapter 2, London: E. Arnold, 1965: 53-145.

18. Davies MJ, Harris A. Pathological basis of primary heart block. Brit Heart J 1969; 31: 219.

19. Andrade ZA, Andrade SG, Oliveira GB, Alonso DR. Histopathology of the conducting tissue of the heart in Chagas' myocarditis. Am Heart J 1978; 93: 316.

20. Spain DM, Cathcart RT. Heart block caused by fat infiltration of the interventricular septum (cor adiposum). Am Heart J 1946; 32: 659.
21. Schwan HP, Kay CF. The conductivity of living tissues. Ann New York Acad Sci 1957; 65: 1007.

22. Köberle F. Pathogenesis of Chagas' disease. In: Trypanosomiasis and Leishmaniasis with Special Reference to Chagas' Disease. Ciba Foundation Symposium 20. Amsterdam: Associated Scientific Publs, 1974: 137-158.

23. Pimenta J, Miranda M, Pereira CB. Electrophysiologic findings in long-term asymptomatic chagasic individuals. Am Heart $J$ 1983; 106: 374.

24. Chiale PA, Przybylsky J, Laino RA, Halpern MS, Sanchez RA, Gabrieli A, Elizari MV, Rosenbaum MB. Electrocardiographic changes evoked by ajmaline in chronic Chagas' disease without manifest myocarditis. Am J Cardiol 1982; 49: 14.

25. Moleiro F, Mendoza I, Octavio JA, Anselmi A, Castellanos A. Los transtornos de conducción intraventricular y la prueba de ajmalina en pacientes con infección chagásica. Rev Lat Cardiol 1982; 3: 414. 